\title{
East or West, Transcending Love is Best
}

ISSN Print: 2576-0556

\author{
Fengjuan Wu, Zhengshun Han* \\ School of Foreign Languages, Wuhan Textile University, Hubei Province, China.
}

How to cite this paper: Fengjuan $\mathrm{Wu}$, Zhengshun Han. (2021) East or West, Transcending Love is Best. Journal of Humanities, Arts and Social Science, 5(2), 189-191.

DOI: $10.26855 /$ jhass.2021.07.002

Received: June 11, 2021

Accepted: July 5, 2021

Published: July 16, 2021

*Corresponding author: Zhengshun Han, School of Foreign Languages, Wuhan Textile University, Hubei Province, China.

Email: hanzhengshun@126.com

\begin{abstract}
As we all know, the American movie Ghost (1990) relates the romantic relationship of Sam and Molly. With the assistance of Carl, his friend and close colleague in bank, they were ready to renovate an old house in New York and got ready to be married. However, one evening, on their way back from a theatre, Sam was attacked by a tall guy from behind unexpectedly. During their scuffle, Sam was lethally wounded while Molly stayed beside him crying for help. From this time on, the phantom of Sam starts to take revenge and protect Molly until he knew all the little details of his murder. It turned out that Carl proved to be the instigator who hired another bad gun keeper to kill him and attempted to secure the code of drawing a large sum of money about 4 million dollars. Coincidentally, HK movie Fly Me to Polaris (1999) deals with a similar love story almost a decade later, but tells it with different characters and plots. By closely watching these two movies, the author makes an attempt to sort out the strands and lines that weaves these beautiful and romantic love stories together from the perspective of Sino-US cross-culture communication.
\end{abstract}

\section{Keywords}

Ghost, Romantic Relationship, Fly Me to Polaris, Cross-Cultural Communication

\section{Introduction}

Throughout history, love remains an eternal theme of human beings. It has been approached home and abroad from diverse perspectives. Here, a special kind of love - transcending love, that is, between human and celestial beings also finds its way into literature since the dawn of human civilization. In the West, transcending love dates back to Hamlet, he and deceased his father's interaction proved to be between man and ghost. Also, Romeo and Juliet represents the typical transcending love story. Besides, in the story of Pygamalion, the Cyprus king falls in love with his own sculptured girl, marries her who under the permission of Venus, Goddess of love, and gives birth to two children for him. In China, in Liang Shanbo and Zhu Yingtai (also called Butterfly Love), somewhat like Romeo and Juliet, moves the hearts of billions. Then in the drama of The Peony Pavilion, Liu Mengmei and Du Liniang also tells the transcending love between man and ghost. In addition, Dong Yong and the Seventh Fairy, another Chinese drama, is concerned with the transcending love between a poor tenant farmer and a fairy. Moreover, the folklore of Cowherd and Weaving Girl in Heaven has been passed from generation to generation. All these are well received and warmly welcomed.

Scholar's research on these two movies includes the following: 1. Ghost. In the paper entitled "Why is the Musical Play of Ghost so Magical?", it is contended that "Unchained Melody” and "Here Right Now" both became the theme song of this movie while "I Had A Life" makes Molly starts to believe the existence of Sam's soul and "With You" describes Molly's endless thinking of Sam (Zhang Li, 2017). Made in 1990, it offers inexhaustible inspirations for other subsequent movies - whether on earth or in heaven, their love never goes far away nor recedes and fades (Evey, 2018); What is love after all? Is it the cloud that floats high over the sky? Or the helpless shell that is left alone after 
the receding tide? Ghost embodies the highest realm of love: they love each other very deeply but unfortunately, in a flash, they departed each other for good (WAERTER, 2017). 2. Fly Me to Polaris. I was terribly touched and moved to tears when I first saw this movie in my puberty, but now after almost 17 years, I had my family and gained a new perception to love. Still, I was crying my eye out (Liu, 2018); I finally got to know what meteoric shower is, it is tears drizzling from the sky (Apricot, 2017); In my best memories: today, I watched this movie again, still moved to tears, too inconsiderate of my appearance. I don't want to mention neither the plot nor love, but your best memory to me. You are kind of baby-fat - smiling with deep dimples in childhood. I cannot find reason for fortitude, no longer feel your gentleness, tell me where the star is and whether there is an end to it (10 Pieces of Classic Review of Fly Me to Polaris: Reflections, 2021). Based on the above, this paper attempts to delineate these two films from three viewpoints: (1) HK movie Fly Me to Polaris must have been inspired from Ghost for three reasons. (2) They share some differences in the meantime. (3) Factors contributing to this are due to distinct cultures and values and beliefs.

\section{The HK Movie Fly Me to Polaris or Xingyuan Must Have Been Inspired from American Movie Ghost}

The reason for this is that, by just looking at the years of release of these two, one will naturally find that: the former was released on August 21, 1999 while the later was made in July 13, 1990, almost a decade later. It is obvious that they are quite identical in both theme and technique. As is said before, they both concern with transcending love between man and ghost. Sam's ghost tried every means possible to discover the truth of his murder and protected her girlfriend from being hurt by so-called his friend Carl and Willie, the killer. He finally managed to revenge on his colleague and get him bleeding to death by cracking him against the door glass, then several shadows appeared and fractured him and took him away to hell and Willie, chased by Sam, finally died in a car accident, just as the saying goes: what goes around comes around. Whereas in the HK film, handsome Ren Xianqi or simply nicknamed Onion who is a mute and deaf for contaminating meningitis and hospitalized youth but finds work in the hospital and develops a tender loving relationship with Qiu Nan or Autumn, a beautiful nurse who also falls in love with him and takes great care of him with tender loving care unawarely. Unfortunately, Onion is knocked down by a car and gets killed on the spot, but his soul rises just then and there. He then goes to heaven and meets an angel who permits him to come back to earth for only five days (for his winning a lottery in paradise) to fulfill his unaccomplished wishes as a stranger of insurance clerk, but nobody would recognize him. Nevertheless, he finds the world entirely different from his own imagination. No one would help him, even his closest friend complains that he is dead, and suggests him not disturb any others for they are too busy. This is in terms of theme. Next, in terms of technique, they both engage in Montague to manifest the transition between this world and the nether world. In both movies, after the hero's death and before he rises to heaven, there occurs a string of shining light dots of small to big sizes from heaven to earth. Of course, there are some minute differences if you watch them carefully. But generally they are of the same type. Finally, after the heroes' death, they all investigate the causes of their death but through different approaches.

\section{These Two Movies Share Some Differences}

The differences lie in the following aspects: (1) Sam and Molly were ready on their way to new wedding and got separated by conspiracy while Onion and Autumn belong to patient and nurse relationship and were separated purely by an accident. (2) After their separation, Sam was unwilling to abandon Molly and still managed to protect her, he even learned some skills from the subway ghost to use his magic forces to move objects and penetrate through walls, and from the black female Spiritual adviser Oda Mae Brown, through her body to communicate with Molly although at first she was a crook who cheated people's money while for Onion, their mutual and deep love was like tacit agreement that was expressed intimately but not so openly as is typical in the east. He disguised as the angel demands him to be and acted as a stranger who can see now and move like normal person but the time span is only five days and just when he wants to reveal his identity, he will be manipulated by the angel for having epilepsy. As the due time comes, he rises to heaven with light from heaven as meteor showers. Simultaneously, Dr. Woo takes Onion's place and always comforts Autumn and they both take pains to show their love to Autumn at Autumn sister's house. So, in the end, when Onion was sure that Dr Woo will protect Autumn as he would do, so he bid his farewell to Autumn and rose to heaven though unwillingly and reluctantly for their once unforgettable and lingering sweet memories.

\section{Factors Contributing to This are Due to Distinct Cultures and Values and Beliefs}

In general, Ghost is an American movie while Fly Me to Polaris is made in Hong Kong-the hub of east and west. However, they represent two different styles of film or polar opposites. Americans strongly believe in individualism, 
that is, "go-it-alone"- the core of western values or "agree to disagree", and believe in "God helps him who helps himself" which can be traced back to the root original sin of Adam and Eve. Whereas in the east, people place much emphasis on collectivism or altruism and treasure the notion "God helps those who help others". In the movies, Sam was characteristic of such a western hero who keeps his promise of love for Molly until justice was done and the two criminals were punished and went to hell, and with his goal accomplished, then he left her and rose to heaven. While Onion was first mute and blind but a very lively and lovely youth who won Autumn's romantic heart. Due to the misfortune, he came back to earth and acted as a stranger to approach Autumn. Finally when he made sure that Autumn would be loved by her colleague Dr Woo, he felt reassured that he would rise to heaven in peaceful manner with the light from above. So this shows that both men are considerate and careful of Autumn so that she would not feel helpless and lonely and abandoned which is true to the easterner's way of thinking: "One good turn deserves another". People tend to do goodism and be kind to others in general. This can be traced back to the thought of "people are born good" by Confucius who is predominant in the Orient as the counterpart of Jesus in the West.

\section{Conclusion}

These two movies have some points in common and some other points not in common. Particularly, Ghost can be regarded as the transcending love movie that others of this kind can model on. Its touching characterization, special technique of Montague, mutual tender loving care and faithful love-eternal theme of humans, theme song-Unchained Melody, and moving scenes, all these remain indelible and deeply imprinted in the audience's heart as classics. Fly Me to Polaris, likewise, touched millions of Chinese movie-goers at the turn of the $21^{\text {st }}$ century, especially as the meteor showers occurred at about that time, people tended to believe in the rising of dear and loving ones after their death to heaven. Well, against the backdrop of the moving — back tide of traditional love, these two movies resonate with audience around the word with different religions, values and cultures, especially the transcending love of valuing "here right now" or just the moment that matters while believing in the ascending of the good to heaven and descending the bad to hell. The writer sincerely believes that after reading this essay, he will, at least, to a certain extent, answer the question raised by Yuan Haowen (1190-1257) of the Jin Dynasty: "Can somebody tell me? What is love supposed to be? That makes me hold no fear in the face of death. With your absence, my existence is meaningless on earth.” See what I mean?

\section{References}

10 Pieces of Classic Review of Fly Me to Polaris: Reflections. https://www.renrendoc.com/paper/115553163.html 2021.2.26.

Apricot. That Year Zhangbozhi was 19 and Ren Xianqi was in his Prime, Why the Promise Made Under the Meteor Showers Moved Millions? http://www.360doc.com/content/17/0405/14/41442829_643046171.shtml. 2017.4.5.

Evey. Ghost. https://movie. Douban.com/Review/9643740/. 2018.9.10.

Liu Junbo: Recreation of Classic Music “Star Rain Star Wish” by Zhang Bozhi in Collaboration with Ren Xianqi http://www.360doc.com/content/18/1219/16/11709004_802913268.shtml 2018 12.19.

WAERTER. Movie Review of Ghost.2017.11.5. http://www.360doc.com/content/17/1105/19/3211232_701145617. shtml.

Zhang Li. "Why is the Musical Play of Ghost so Magical?”. Dramatic Criticism. 2017.0025.14-17. 